\title{
GREGORY NAZIANZEN'S USE OF SCRIPTURE IN DEFENCE OF THE DEITY OF THE SPIRIT
}

\section{T. A. Noble}

Gregory Nazianzen's defence of the deity of the Spirit was most fully expressed in two orations which he gave in Constantinople during his brief sojourn there from AD 379 to AD 381. He was summoned to Constantinople in 379 by the orthodox remnant adhering to the Creed of Nicaea. The churches of the capital had been in the hands of the Arians for several decades, but the accession of an orthodox emperor, Theodosius, heralded the eclipse of Arianism, and Gregory left his retirement by the sea and hurried to Constantinople where he established the Nicene congregation in the aptly named private chapel of the Resurrection, the Anastasia. It was there at Pentecost, 379 that he delivered his oration On Pentecost (now numbered Oration 41), ${ }^{1}$ and there too that he delivered, probably the following Spring in 380, his celebrated Five Theological Orations on the Trinity. The fifth of these, On the Spirit (now numbered Oration 31 ), ${ }^{2}$ possibly delivered at Pentecost, 380, is the most complete statement of his pneumatology. 3

It will be helpful first, before examining the Fifth Theological Oration and particularly its use of Scripture in defending the Spirit's deity, to place Gregory's contribution in the context of the debate on the Spirit and to summarize as

${ }^{1}$ Oration 41, J.P. Migne, Patrologiae Graecae (hereafter PG) XXXVI, 427-52. Eng. trans. by C.G. Browne and J.E. Swallow, Nicene and Post-Nicene Fathers, second series, VII, 378-85.

2Oration 31, PG XXXVI, 133-72; Eng. trans. NPNF, VII, 318-28, and in Christology of the Later Fathers, ed. E.R. Hardy and C. Richardson (Library of Christian Classics) 194-214.

${ }^{3}$ Paul Gallay, La vie de Saint Grégoire de Nazianze (Lyons and Paris: Vitte, 1943) 137 ff., dated the Five Theological Orations in Autumn of 380. J.M. Szymusiak, 'Pour une chronologie des discours de S. Grégoire de Nazianze', Vig. Chr., 20 (1966) 183-9, dated them during Lent, 380, with the fifth at Pentecost. 
succinctly as is possible the complex Arian controversy which provides the wider background.

\section{The Arian Controversy and the Debate on the Spirit}

The debate on the status of the Holy Spirit in the late fourth century may be regarded as part of the final chapter of the Arian controversy. Arius began to express his views on the status of the Son as early as 318 and published his letter to bishop Alexander of Alexandria (which is one of our main sources for his theology) in the early $320 \mathrm{~s}^{4}$ According to this, God [the Father] was alone unbegotten (i.e., unbegun) and eternal, and the Son was a perfect creature who, before the ages, was begotten or created - to Arius the two words meant the same thing. This view of the Son as a kind of created demi-god or archangel provoked sufficient reaction throughout the church to secure agreement in 325 at the council of bishops called to Nicaea by the Emperor Constantine that Arianism must be condemned. Agreement was secured for a definitive creed, the original Nicene Creed, which safeguarded the deity of the Son by declaring that he was 'of one substance $(\delta \mu o o v \sigma L v)^{\prime}$ with the Father. It is possible that this word was chosen because of the influence of Ossius of Cordova, one of the few Western bishops present, who was nevertheless influential as the Emperor's ecclesiastical adviser. If so, the word $\delta \mu$ ov $\sigma\llcorner 0 \nu$ may reflect the prevalence in the West of Tertullian's Trinitarian formula, three persons in one substance. It may be, on the other hand, that the word opoovolov was selected simply to isolate the Arians and (as Ambrose later suggested) because it was the very word the Arians rejected, without any clear understanding of what the word positively meant. 5

The renewed controversy after 325 suggests that the meaning of $\delta$ roovolov had not been fully clarified. The

${ }^{4}$ Hardy and Richardson, op. cit., 332-4.

${ }^{5} \mathrm{Cf}$. Christopher Stead, Divine Substance (Oxford: Clarendon, 1977) 250ff. Cf. also Alasdair I.C. Heron, 'Homoousios with the Father', in The Incarnation, ed. T.F. Torrance, (Edinburgh: Handsel, 1981) 58-87, esp. 63f. (first pub. in Abba Salama, 10 (1979) 133-56). 
writings of Marcellus of Ancyra, a strong supporter of the Nicene settlement, produced a strong reaction. Marcellus so emphasized the $\delta$ poovolov and the union of Father, Son and Holy Spirit in the one substance that he denied that the distinctions between them were eternal. The majority of Eastern bishops, standing in the tradition of Origen which asserted the eternal distinction of Father, Son and Spirit as distinct $\dot{u} \pi 0 \sigma \tau d \sigma \epsilon \iota s$, or 'objective realities', ${ }^{6}$ could not but regard this as a revival of the Sabellian heresy of the previous century. ${ }^{7}$ The word $\delta \mu 00 v \sigma i \nu \nu$ therefore fell out of favour with this broad central tradition, usually, but misleadingly, referred to as 'semi-Arians'. A group of them led by Basil of Ancyra, Marcellus' successor as bishop, have been called Homoiousians since it was said that they wished to

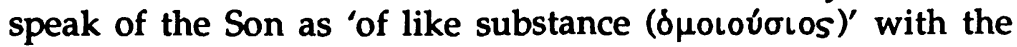
Father. But the emergence of a more extreme Arian faction, the Neo-Arians, led by Aetius and Eunomius threw them back into the arms of the Nicene party, the supporters of $\delta \mu o o b \sigma o v .{ }^{8}$

Thanks to the statesmanship of Athanasius of Alexandria at the Council of Alexandria in 362, a rapprochement was reached between the Nicene party and the broad central Eastern tradition which followed Origen in speaking of Father, Son and Holy Spirit as three ímootd́бets, Although Athanasius himself and the Nicene party preferred to equate intortaris with oivla (substance) and to speak of the

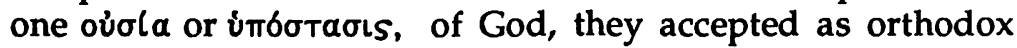

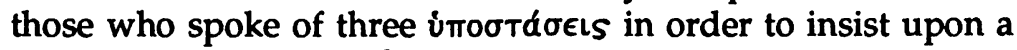
truly subsisting Trinity. ${ }^{9}$

It was this latter group, the broad central Eastern

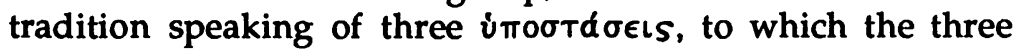

\footnotetext{
${ }^{6}$ Cf. G.L. Prestige, God in Patristic Thought (London: SPCK,1952) $162 \mathrm{ff}$.

${ }^{7}$ Marcellus was not strictly speaking Sabellian. Sabellius developed Modalistic Monarchianism or Patripassianism originally expounded by Noetus and Praxeas. According to Sabellius, God was successively Father, Son and Holy Spirit. But according to Marcellus, the Son and Spirit, who originally came forth from the Father for the creation of the world would be reabsorbed into the Father once salvation was completed.

${ }^{8}$ Thomas A Kopecek, A History of Neo-Arianism (Philadelphia: Patristic Foundation, 1979). Cf. Heron, op. cit., 65f., for a brief account.

${ }^{9}$ Cf. Athanasius, Tomus ad Antiochenos, Eng. trans. in NPNF, IV, 481-6.
} 
Cappadocian Fathers, Basil, Gregory of Nazianzus and Gregory of Nyssa, belonged. Basil, who became Archbishop of Caesarea, the Cappadocian capital, in 370, distinguished

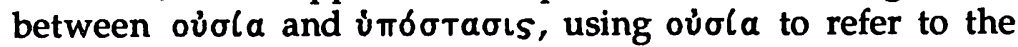
substance or essence of the Godhead, that is to say, all that is common to Father, Son and Holy Spirit, and imorraols, as the equivalent of the Western 'person' to refer to Father, Son and Spirit in particular. He thus established as the standard expression of orthodoxy in the East the formula one ovola,

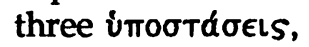

The Arian controversy was thus not only a dispute about the deity of the Son, but inextricably involved in that a dispute about the God whose deity was attributed to the Son, in other words, a debate about the Trinity.

It was in the later stages of the controversy that the question of the deity of Spirit was specifically raised. In 359 or 360 Athanasius wrote his Letters to Serapion in which he defended the deity of the Spirit against an obscure Egyptian group whom he dubbed the Tropici. ${ }^{10}$ Fifteen years later in 375, the treatise On the Holy Spirit was completed by Basil, from whose pen, according to R.P.C. Hanson, came 'the most important work on the theology of the Holy Spirit done in the fourth century.'11 Basil's treatise seems to have been written in response to the arguments of the Pneumatomachi, or 'Spiritfighters', a group who were apparently orthodox on the deity of the Son but who denied the deity of the Spirit. Unlike the Tropici, who seem to have been an Egyptian group, the Pneumatomachi seem to represent a fairly widespread tendency in the Greek-speaking church.

When Gregory arrived in Constantinople in 379, the city was alive with theological controversy and most of the Christian factions seem to have been represented. F.W. Norris

${ }^{10}$ C.R.B. Shapland, The Letters of St. Athanasius concerning the Holy Spirit (Epworth, London, 1951). On the Tropici, cf. A.I.C. Heron, 'Zur Theologie der "Tropici" in den Serapionbriefen des Athanasius: Amos 4:13 als pneumatologische Belegstelle', Kyrios 14 (1974).

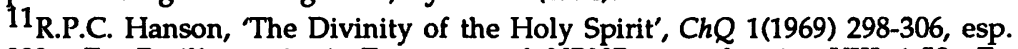
300. For Basil's treatise in Eng. trans. cf. NPNF, second series, VIII, 1-50. For the Greek text cf. C.F.H. Johnston, Saint Basil on the Holy Spirit (Oxford: Clarendon, 1892). 
argues from the Fifth Theological Oration that there were at least four major views on the Holy Spirit. ${ }^{12}$ First, there were those who believed that the Spirit was God, but they were divided on whether this should be openly confessed. Secondly, there were those who were agnostic about the deity of the Spirit 'out of reverence for Scripture'; ${ }^{13}$ believing that Scripture gave no clear indication. Thirdly, there were the Pneumatomachi, sometimes called Macedonians after Macedonius, a previous Archbishop of Constantinople. Fourthly, there were the extreme Neo-Arians or Eunomians, whom Norris regards as the main opponents Gregory has in mind in the Fifth Theological Oration. Clearly for all four groups the teaching of Scripture was of fundamental importance and the lack of a clear and explicit statement in Scripture, 'the Holy Spirit is God', was a major point in the debate. Even among the orthodox who believed in the Spirit's deity there were those who took the position that since it was not explicitly stated in Scripture, they were not free to state it either, and must maintain a reverent silence. To them it was not permissible to go beyond the clear statements of Scripture. The same reverence for Scripture was the reason for the agnosticism of the second group and was a decided polemical advantage for the Pneumatomachi and the Eunomians who denied the Spirit's deity.

2. Gregory and Basil on the Role of Scripture.

It is the last group, the Eunomians, whom Gregory has in mind as he begins the Fifth Theological Oration, On the Spirit. In the Fourth Theological Oration he had defended the deity of the Son against them. He begins the Fifth by posing the question they ask:

\footnotetext{
${ }^{12}$ F.W. Norris, 'Gregory Nazianzen's Opponents in Oration 31', a paper read at the Oxford Patristic Conference of 1983 which will presumably be published in a forthcoming volume of Studia Patristica, XVIII.

${ }^{13}$ Orat. 31:5, PG XXXVI, 137C.
} 
But, they go on, what have you to say about the Holy Spirit? From whence are you bringing in upon us this strange and unscriptural God ( $\xi \in v O v$ oedv kal drpaфov)? ${ }^{14}$

Gregory's charge against those who are angry with him for bringing in 'a certain strange or interpolated God ( $\xi \in$ Evov TLvd

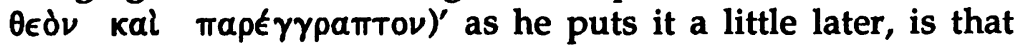
they fight so very hard for the letter of Scripture but that 'their love for the letter is but a cloak for their impiety'. ${ }^{15}$ The view of Scripture on the status of the Spirit is clearly to be a crucial issue in the argument of the oration. Before following the course of Gregory's argument, however, it would be helpful to take a slight digression to consider briefly how Basil had dealt with the same issue five years earlier in his treatise $O n$ the Holy Spirit.

The immediate occasion of the writing of Basil's treatise was a dispute in the church at Caesarea in Cappadocia about the doxology. In addition to the traditional doxology, 'Glory be to the Father through the Son in the Holy Spirit', Basil had introduced what some considered to be an innovation, glorifying the Father 'with ( $\mu \epsilon \tau d)$ the Son together with $(\sigma i v)$ the Holy Spirit'. ${ }^{16}$ Clearly this implied the equality of Father, Son and Spirit in a way which the first did not. When this provoked protests, Amphilochius, the bishop of Iconium (and cousin of Gregory of Nazianzus), who was present, requested Basil to write a treatise defending the deity of the Spirit. But there was more to the background of the treatise than this request. For some years Basil had been in dialogue with his neighbouring archbishop, Eustathius of Sebaste. Eustathius had been a leader of the so-called Homoiousian party along with Basil of Ancyra, and Basil of Caesarea had been briefly associated with them as an outstanding young rhetor straight from his studies in Athens. ${ }^{17}$ Basil admired Eustathius for his asceticism, but his doctrinal convictions seem

${ }^{14}$ Orat. 31:1, PG XXXVI, 133B.

${ }^{15}$ Orat. 31:3, PG XXXVI, 136B.

${ }^{16}$ On the Holy Spirit, I(3). Cf. the description of the circumstances by B. Pruche in Basile de Césarée: Traite du Saint-Esprit, (Sources chrétiennes 17, Paris: Cerf, 1946).

${ }^{17}$ Thomas A Kopecek, op.cit., $300 f$. 
to have lacked clarity. Blomfield Jackson called him 'the Vicar of Bray of the Arian controversies, who probably subscribed more creeds than any other prominent bishop of his age ${ }^{18}$ Basil had spent two days in 372 persuading Eustathius to accept the deity of the Spirit. But no sooner had Basil departed than Eustathius repudiated this 'protocol of Sebaste'. Basil's arguments in this treatise written three years later seem to have been directed specifically against Eustathius who now stood forward as a leading Pneumatomachian. ${ }^{19}$

R.P.C. Hanson sees this as the explanation for an unprecedented development in Basil's case:

Basil could not meet Eustathius' demand for a full documentation from Scripture of his doctrine of the Holy Spirit. The methods of interpreting the Bible which were accepted and conventional in the fourth-century Church simply did not admit of such a possibility. Basil was quite perspicacious enough to realize this. So he took the alternative course of developing to an extent not previously achieved the support which extra-scriptural tradition could give to the Church's doctrine. ${ }^{20}$

Hanson maintains that whereas previously Basil had shared the view of Athanasius that 'Scripture is doctrinally sufficient', ${ }^{21}$ in this treatise he takes quite a new step. He deals with the scriptural evidence 'briefly, without much success or conviction', and then proceeds to defend the deity of the Spirit by claiming that tradition independent of the Bible is important, indeed essential, in doctrinal matters'.22 If this is a fair assessment of Basil's position, his doctrine of tradition is, as Hanson comments, 'a startling innovation'.23

If then Basil in $\mathbf{3 7 5}$ found it necessary to appeal to tradition to establish the deity of the Holy Spirit because he

\footnotetext{
${ }^{18}$ NPNF, second series, VIII, 194, n 3.

${ }^{19}$ Hermann Dörries, De Spiritu Sancto. Der Beitrag des Basilius zum Abschluss des Trinitarischen Dogmas (Göttingen: Vandenhoeck \& Ruprecht, 1956) 86.

${ }^{20}$ R.P.C. Hanson, 'Basil's Doctrine of Tradition in Relation to the Holy Spirit', Vig.Chr. 22 (1968) 241-55, cf. 252-3.

21 Ibid., 244.

22 Ibid., 249.

23Ibid., 251. Cf. Georges Florovsky, Bible, Church Tradition: An Eastern Orthodox View (Belmont, Mass: Nordland, 1972), 85ff. Florovsky argues that Basil does not introduce a double authority, Scripture and Tradition. The 'unwritten tradition' to which he refers does not add anything to the content of the scriptural faith: it only puts this faith in focus.
} 
regarded Scripture as insufficient and inconclusive, it is worthy of comment that four years later, a year after the death of Basil, his friend Gregory of Nazianzus found such a step unnecessary. 24 Gregory and his opponents were agreed that the teaching of Scripture was decisive, and as he began his Fifth Theological Oration, it was to the charge that the Holy Spirit was 'a strange and unscriptural God' that Gregory addressed himself. According to Plagnieux nothing was more significant for Gregory than 'the scriptural proof which establishes the deity of the Spirit against the Pneumatomachi and of which the Fifth Theological Oration contained the definitive exposition'.25

\section{Scripture and Theological Coherence.}

It must be admitted that at first Gregory does not appear to make much headway in presenting 'scriptural proof'. Rather than proceeding to establish his case by careful exegesis, he lays aside the examination of the words 'spirit' and 'holy' and the title 'Holy Spirit' in Scripture, and begins boldly from the doctrine of the Trinity.

But we have so much confidence in the deity of the Spirit whom we adore that we will begin our teaching concerning his deity by fitting to him the names which belong to the Trinity, even though some persons may think us too bold. ${ }^{26}$

Bold Gregory certainly is, for he begins by applying John 1:9 to the three Persons of the Trinity without pretending to provide any exegetical justification. He proclaims:

The Father was 'the true Light, which lightens every man coming into the world'. The Son was 'the true Light, which lightens every man coming into the world'. The other Paraclete was the 'true Light, which lightens every man

${ }^{24}$ Hanson, op.cit., 253f. Yet see the positive place Gregory gave to tradition according to Henri Pinault, Le Platonisme de Saint Grégoire de Nazianze (La Roche-sur-Yon: Romain, 1925), 32ff.

${ }^{25}$ J. Plagnieux, Saint Grégoire de Nazianze Théologien (Paris, 1952), 41. Cf. Ibid., 49f. on Gregory's view if the role of tradition. F.W. Norris discusses Gregory's views of Scripture and tradition in Gregory Nazianzen's Doctrine of Jesus Christ (unpub. Ph.D. thesis,Yale, 1970) 17ff.

${ }^{26}$ Orat. 31:3, PG XXXVI, 136B. 
coming into the world'. 'Was' and 'was' and 'was', but was one thing. 'Light' and 'Light' and 'Light' but one Light and one God."

'It must be admitted,' commented Henri Pinault, 'that [Gregory] sometimes accommodates such biblical texts to his doctrine, such as the prologue of St. John, applied to the Trinity. ${ }^{28}$ Yet, as Pinault continues, Gregory himself has confessed that this accommodation could appear quite audacious, and beside this passage one could cite many more which express precisely the deity of each of the three persons in a way which authorizes this accommodation of John 1:9.

If John 1:9 is not then presented here as an exegetical foundation for the deity of the Spirit, Gregory's next biblical citation will advance this cause no farther in the eyes of the modern exegete. For Gregory claims that the triple light of the Trinity was what David proclaimed when he said, in Psalm $36: 9$, 'In thy light we shall see light'. ${ }^{29}$ The Father is the one being addressed here, according to Gregory, and he, being light, is the source of that light, the Spirit, by whom we see light, the Son. In the context it is doubtful if this is presented as an exegetical basis for the doctrine. Rather the claim is that given the doctrine of the Trinity this text can be interpreted in this way. But Gregory does not imagine that such a use of the text will persuade anyone beginning from a different premiss.

He that rejects it, let him reject it, and he that does iniquity, let him do iniquity; we proclaim that we have understood. ${ }^{30}$

As Pinault reminds us, Gregory provides exegetical foundation elsewhere. It must not be forgotten that the Fifth Theological Oration follows the previous four in which Gregory spends a considerable amount of time on exegetical questions, particularly in the third and fourth. In the Third Theological Oration Gregory had first defended the theological coherence of the doctrine of the eternally unbegotten Father and the eternally begotten Son within the

27 Ibid.

28 Pinault, op.cit., 216.

${ }^{29}$ Orat. 31:3, PG XXXVI, 136C. Cf. Orat. 34:13, PG XXXVI, 253A. Cf. Basil, On the Holy Spirit, XVIII (47). Ps. 36:9 was frequently used by the Fathers.

30 Ibid. 
unity of the Godhead, and then had turned as the climax of the oration to Scripture:

But now, since we have ascertained how invincible you are in your arguments and sophistries, let us look at your strength in the oracles of God, if perchance you may choose to persuade us out of them. For we have learned to believe in and to teach the deity of the Son from their great and lofty utterances. ${ }^{31}$

He then proceeds to look at the scriptural basis for the Son's deity. The Fourth Theological Oration is exegetical throughout, dealing with the Arian exegesis of their favourite proof-texts before concluding with a review of the Christological titles in Scripture.

Here in the Fifth Theological Oration, then, dealing with the deity of the Spirit, Gregory follows a procedure similar to that in the third. There he dealt with the coherence of the doctrine of the eternal generation of the Son from the Father before concluding with the scriptural evidence for the deity of the Son. Now he deals with the coherence of the doctrine of the Trinity with particular reference to the Spirit, and once again, having cleared the difficulties out of the way, Gregory, as a skilled orator, will bring the oration and the whole series to a climax with his weightiest arguments, the scriptural basis for the Trinity and for the deity of the Spirit in particular.

Before turning to Gregory's main argument from Scripture in the concluding sections of the oration, it will be useful to trace briefly the course of the argument for the theological coherence of the doctrine, which is not without appeal to Scripture. Having begun by applying the titles of the Trinity to the Spirit (or, at least, the title 'Light'), and having asserted that the Spirit is co-eternal with the Father and the Son since the Godhead could never have been imperfect, Gregory decides to reason 'from a somewhat earlier point, since we have already discussed the Trinity'.$^{32} \mathrm{He}$ begins by setting out an argument for the deity of the Spirit. Given the existence of the Spirit, we must conceive of him as either a substance (ovj $\sigma(\alpha)$ or accident ( $\sigma u \mu \beta \epsilon \beta \eta \kappa \delta s)$. Gregory

31 Orat. 29:16-17, PG XXXVI, 96B.

32Orat. 31:5, PG XXXVI, 137B. 
uses conventional terminology stemming from Aristotle to pose the alternatives that the Spirit is either an objective reality in himself or a quality or attribute existing in an objective reality, in which case he would be an activity ( $\varepsilon^{\prime} \epsilon_{\rho \gamma \epsilon L a)}$ of God. The question is determined by reference to Scripture, for it speaks of the Spirit acting and speaking and being grieved and angered. ${ }^{33}$ If he is then, as this implies, an objective reality in himself, he must either be a creature or God. Since we believe in him and are perfected by him, he cannot be a creature. This second step is taken without reference to Scripture (which speaks neither of believing in the Spirit nor of being perfected by him), but Gregory still stops short of concluding explicitly that the Spirit is God.

Instead Gregory first considers an objection to the Spirit's deity, a dilemma his opponents loved to pose (presumably this time the Pneumatomachi), and which raises the question of the coherence of the doctrine of God when deity is ascribed to the Spirit. If the Spirit is God, according to the Pneumatomachi, he must either be unbegotten or begotten. If unbegotten, there will be two first principles or 'fathers'. If begotten, there will be two 'sons' (who will be 'brothers') or, if begotten from the 'son', a 'son' and a 'grandson'. ${ }^{34}$ Gregory responds to the conundrum by refusing the alternatives. Here he draws on Scripture to provide another possibility, that the Spirit is neither unbegotten nor begotten but, as in John 15:26, the one who proceeds from the Father. But the substantive point here is not the word drawn from Scripture but the logical point that the alternatives presented do not exhaust the possibilities. Indeed, as Gregory reminds them, we do not know what 'generation' means in God any more than we know what 'procession' means, and if we attempt to discover it, 'we shall both of us be frenzy-stricken for prying into the mystery of God'.35 His opponents' dilemma is therefore merely an

33 Orat. 31:6, PG XXXVI, 140A; ref. to Acts 13:2; Eph. 4:30; Isa. 63:10.

${ }^{34}$ Orat. 31:7, PG XXXVI, 140C. Athanasius considered the same conundrum in the Letters to Serapion I, 15-16, but met it with a different argument, that the words 'father' and 'son' keep to their strict meaning only in reference to God Other implications may be present when these words are used to refer to men, but these do not apply to God.

${ }^{35}$ Orat. 31:8, PG XXXVI, 141B. 
argument about words. To insist that each of the Persons of the Trinity must either be 'unbegotten' or 'begotten', that is to say, must either be 'Father' or 'Son', is farther than we may go. We may speak of the coming forth of the second person from the first person using the analogy of the generation of a son from a father. ${ }^{36}$ But the coming forth of the third person is so ineffable that we are given no comparable analogy or model and can only say that he 'comes forth' or 'proceeds'. The different names given to each person in Scripture thus indicate, according to Gregory, that the Son and the Spirit come forth from the Father in different ways. He explains:

The difference of manifestation (eKфávots - coming forth into view), if I may so express myself, or rather of their mutual relations one to another, has caused the difference of their names... The very fact of being unbegotten or begotten, or proceeding, has given the name of Father to the first, of the Son to the second, and to the third, him of whom we are speaking, the Holy Spirit, that the distinction of the three hypostases may be preserved in the one nature and dignity of the Godhead. ${ }^{37}$

Having disposed of his opponents' dilemma which had attempted to show that the deity of the Spirit resulted in an unacceptable doctrine of God, Gregory is ready for his ringing declaration:

What, then? Is the Spirit God? Most certainly. Well, then, is he consubstantial? If he is God, yes. ${ }^{38}$

The unbegotten, the begotten and the one who proceeds are all of the one substance, deity, just as Adam who was created, Eve, who was formed from a fragment of Adam, and Seth, who was begotten of both, were all of one substance, humanity. ${ }^{39}$ But whereas humanity has a unity only conceivable in thought, with each human being parted from the others in time and

${ }^{36}$ Gregory and his contemporaries inherited the doctrine of the eternal generation of the Son from the Father from Origen and Athanasius. For the different role this doctrine played in the thought of these two theologians, cf. Maurice F. Wiles, 'Eternal Generation', JTS 12 (1961) 284-5, and E.P. Meijering, 'Athanasius on the Father as the Origin of the Son', God Being History (Oxford, 1975) 89-102.

37Orat. 31:9, PG XXXVI, 141C-144A.

${ }^{38}$ Orat. 31:10 PG XXXVI, 144A.

${ }^{39}$ Orat. 31:11, PG XXXVI, 144D-145A. 
distance, each of the Three in the Trinity is united no less to the others than to itself by identity of being.

The Godhead is, to speak concisely, undivided in its divisions ( $\alpha \mu t p l o t o s$ Ev

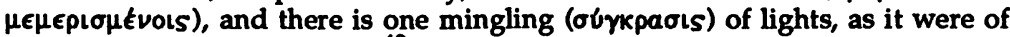
three suns holding each other..$^{40}$

This central major section of the oration, which argues for the deity of the Spirit by shewing that it is integral to the doctrine of God as the Holy Trinity, draws to a close by disposing of one or two objections. These are arguments, says Gregory, which are laughable, assuming as they do that realities $(\pi \rho \alpha \gamma \mu \alpha \tau a)$ are determined by words or names $(\delta \nu \delta \mu a T a)$. And with this significant distinction he passes in the concluding section of the oration from theological coherence to scriptural proof.

\section{Interpreting Scripture.}

Having defended the coherence of the doctrine of the deity of the Spirit by placing it in its theological context within the doctrine of the Trinity, Gregory now passes to the grounds for the deity of the Spirit and comes at last to the charge with which he began, that he is interpolating 'a strange and unscriptural God'.

Over and over again, you turn upon us the silence of Scripture (to; a[grafon). But that it is not a strange doctrine, nor an afterthought, but acknowledged and plainly set forth both by the ancients and many of our own day, is already demonstrated by many persons who have treated of this subject and who have handled the Holy Scriptures, not with indifference or as a mere pastime, but have gone beneath the letter and looked into the inner meaning, and have been deemed worthy to see the hidden beauty, and have been irradiated by the light of knowledge. ${ }^{41}$

Here incidentally is Gregory's positive understanding of the role of tradition. He is conscious that in interpreting the Scriptures to imply the deity of the Spirit he stands in what he would regard as the orthodox tradition of the Church. Tradition is thus not an independent source of doctrine for Gregory but an historical continuity of interpretation of

${ }^{40}$ Orat. 31:14, PG XXXVI, 149A.

${ }^{41}$ Orat. 31:21, PG XXXVI, 156CD. 
Scripture. He accepts that it is necessary 'to go beneath the letter ( $\delta(\alpha \sigma \chi \delta \delta \tau T \in S$ To $\gamma \rho \alpha \mu \mu \alpha)$ ' and 'to look into the inner

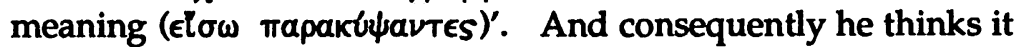
necessary to preface his argument for the deity of the Spirit from the Scriptures with a brief discussion of his hermeneutical approach. He begins:

Since the fact that Scripture does not very clearly or very often write him God in express words, as it does first the Father and afterwards the Son, becomes to you an occasion of blasphemy and of this excessive wordiness and impiety, we will release you from this inconvenience by a short discussion of things and names

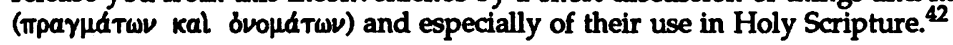

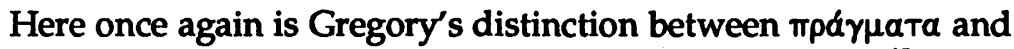

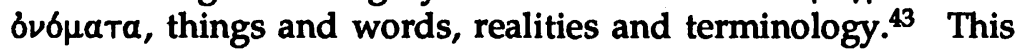
fundamental distinction is the basis for the four-fold classification he now proposes. Some things or situations do not exist but are spoken about in the Scriptures, for example, that God sleeps and awakes, is angry, or walks. These are not facts, says Gregory, but figures of speech. Secondly, some things or situations do exist but are not explicitly stated in Scripture, for example, says Gregory as a skilled debater, the facts so fundamental to the theology of his opponents, the Neo-Arians, that God is 'unbegotten' and 'unoriginate'. These words do not appear in Scripture, yet what they state about God is true. Thirdly, some things neither exist nor are spoken about, for example, that God is evil or that a sphere is square. And fourthly, some things both exist in fact and are stated in Scripture, for example, God, man, judgment and, he adds for the benefit of his opponents, vanities, 'such as your arguments'.

Clearly the important category for Gregory's argument is the second one - facts, things, realities, states of affairs which exist and are so, but which are not explicitly stated in the Scriptures. Gregory proceeds to draw the conclusion:

If, when you said twice five or twice seven, I concluded from your words that you meant ten or fourteen; or if, when you spoke of a rational and mortal animal [I concluded] that you meant man, should you think me to be talking nonsense?

42 Orat. 31:21, PG XXXVI, 157A.

${ }^{43}$ Gregory develops this point presumably partly in reaction to the Eunomian doctrine that names are annexed to essences in such a way that a different name implies a different essence. Cf. L.R. Wickham, 'Aetius and the Doctrine of Divine Ingeneracy', Studia Patristica XI (1972) 259-63. 
Surely not, because I should merely be repeating your own meaning; for words do not belong more to the speaker than to him who elicits them. As then in this case, I should have been looking, not so much at the terms used as at the thoughts they were meant to convey. ${ }^{44}$

Words such as 'unbegotten' or 'unoriginate' are due to 'passages

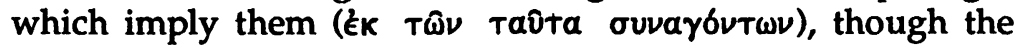
words do not actually occur'. Clearly the same may be said for the word 'consubstantial ( $\delta \mu o o v \sigma(o v)$ ' and for the statement that the Spirit is God. Plagnieux suggests the term 'spiritual realism' to describe Gregory's approach.45 F.W. Norris considers that commentators who have examined Gregory's exegetical procedures have been too restricted by a stilted classification distinguishing between Alexandrian allegorical interpretation and the historical-grammatical interpretation of the Antiochenes. ${ }^{46} \mathrm{He}$ considers that in exegesis Gregory has close affinities to Origen and that he 'seems to desire some middle way through the extremes of interpretation as he sees them, some road which will avoid the pitfalls of Jewish imprisonment in the letter and unlearned flight into fanciful allegory'.47 But if Gregory's exegetical procedures were influenced by Origen, as Norris argues, it is reasonable to suggest that the hermeneutical approach outlined in this passage, characterised by 'spiritual realism', may be influenced as much by Athanasius. In Athanasius, according to T.F. Torrance, 'the language of Scripture points away from itself to independent realities and is to be understood by acts in which we look at it, refer it back to its source, discriminate the realities indicated and so determine the meaning of what is written according to the nature of the things signified' ${ }^{48}$ For Gregory as for Athanasius, the meaning of the ovónata, the words of Scripture, lies in the $\pi \rho d \gamma \mu a t a$, the divine realities, to which they refer. And the words may imply more than they explicitly state. Gregory has now prepared the ground to demonstrate that even though the Scriptures may not include

${ }^{44}$ Orat. 31:24, PG XXXVI, 160BC.

45. Plagnieux, op.cit., 46.

46 F.W. Norris, op.cit., 21.

47 Ibid.,24. For examples, cf. ibid., 24-9.

${ }^{48}$ T.F. Torrance, 'The Hermeneutics of St. Athanasius', Ekklesiasticos Pharos, 52 (1970) 446-68; 89-106, 231-49; 53 (1971) 133-49. Cf. 52 (1970) 455. 
an explicit statement that the Spirit is God, they clearly imply it.

\section{Progressive Revelation}

Gregory is ready now to explain why the Scriptures are so cautious in stating the deity of the Spirit. He will explain 'the reason for all the reticence', ${ }^{49}$ by expounding his view of gradual or progressive revelation. He begins:

There have been in the whole period of the duration of the world two conspicuous changes of men's lives, which are also called two Testaments, or, on account of the wide fame of the matter, two earthquakes: the one from idols to the law, the other from the law to the gospel. ${ }^{50}$

In the first change, under the Old Covenant, idols are cut off, but sacrifices still allowed. In the second, when the New Covenant is inaugurated, sacrifices are cut off but circumcision still allowed. In this way God brings about a gradual reform of human customs. Theology, or the doctrine of God, proceeds similarly but by additions instead of subtractions. Gregory explains:

The Old proclaimed the Father openly, and the Son more obscurely. The New manifested the Son, but showed the deity of the Spirit covertly. Now the Spirit dwells among us and supplies to us more clearly his self-revelation. ${ }^{51}$

The reason for the reticence was our incapacity to receive the truth. It was for our sakes that the revelation of the Trinity was made gradually. Otherwise we would not have been able to receive it. In keeping with this gradual revelation of $\mathrm{God}$ as the Holy Trinity, the Spirit himself is gradually revealed during the life of Christ.

For this reason it was, I think, that he gradually came to dwell in the disciples, measuring himself out to them according to their capacity to receive him, at the beginning of the gospel, after the Passion, after the ascension, making perfect their powers, being breathed upon them, and appearing in fiery tongues. ${ }^{52}$

Before the Passion, Gregory says,

${ }^{49}$ Orat. 31:24, PG XXXVI, $160 \mathrm{C}$.

${ }^{50}$ Orat. 31:25, PG XXXVI, 160D.

51 Orat. 31:26, PG XXXVI, 161C.

52Orat. 31:26, PG XXXVI, 164A Cf. Orat.41:11. 
our Saviour had some things which, he said, could not be borne at that time by his disciples... and therefore they were hidden. And again he said that all things should be taught us by the Spirit when he should come to dwell amongst us. Of these things one, I take it, was the deity of the Spirit himself, made clear later on... after our Saviour's restoration... ${ }^{53}$

Gregory concludes his review of progressive revelation with the argument that since the Spirit deified him in baptism, the Spirit must be worshipped, and since he is worshipped, he is an object of adoration, and if an object of adoration, he must be God. 'The one is linked to the other, a truly golden and saving chain.'

And indeed from the Spirit comes our new birth, and from the new birth our new creation, and from the new creation our deeper knowledge of the dignity of him from whom it is derived. ${ }^{54}$

Gregory's view of progressive revelation has been acclaimed. Lebreton said that it was 'justly celebrated'. ${ }^{55}$ More recently, Norris has referred to Gregory's 'stunning views of the order of revelation' ${ }^{56}$ R.P.C. Hanson regards it as a 'very interesting theory of progressive revelation extending beyond Scripture', ${ }^{57}$ and regards it as more satisfactory than Basil's argument from secret tradition. The question must be posed, however, whether Gregory is envisaging revelation 'extending beyond Scripture' and, if so, in what sense.

It is true that Gregory's view of progressive revelation is introduced as an explanation for to a ypaфov, 'the unwritten' or 'the unscriptural', or, as it is usually translated, 'the silence of Scripture'. It was because men were not ready to receive the deity of the Spirit which was 'food beyond their strength', light too strong for 'eyes as yet too weak to bear it' ${ }^{58}$

It might appear therefore that Gregory is explaining the silence of Scripture on the deity of the Spirit by saying that

\footnotetext{
${ }^{53}$ Orat. 31:27, PG XXXVI, 164BC.

${ }^{54}$ Orat. 31:28, PG XXXVI, 165A.

55 Jules Lebreton, Les Origines du dogme de la Trinite (Paris: Beauchesne, 1910) 89-90.

${ }^{56}$ F.W. Norris, 'Gregory Nazianzen's Opponents', op. cit.

57 R.P.C. Hanson, 'The Divinity of the Holy Spirit', op cit., $300 f$.

${ }^{58}$ Orat. 31:26, PG XXXVI 161C.
} 
it was a post-Scriptural revelation. ${ }^{59}$ A closer examination of what Gregory actually says, however, makes this explanation unlikely. What Gregory is saying is that the deity of the Spirit was not clearly revealed during the earthly life of Christ. When he says that 'the Old ( $\eta \pi$ mala $\alpha$ )' revealed the Father clearly and the Son obscurely, whereas the New (in Kaiv' f)' revealed the Son, but covertly or secretly showed the deity of the Spirit, whereas 'now' the Spirit dwells among us and supplies us with a clearer revelation of himself, ${ }^{60}$ he is not referring to the Old Testament Scriptures, the New Testament Scriptures and the post-scriptural period. Rather in the light of the succeeding paragraphs, he is speaking about the Old Testament period, the period of the Son's dwelling on earth from the incarnation to the ascension, and the post-Pentecost period. The word 'now', in this context, refers to the present age beginning at Pentecost. Similarly in Oration 41, $\mathrm{On}$ Pentecost, Gregory speaks of 'the present distribution of fiery tongues which we are now commemorating' (literally the 'now' distribution). ${ }^{61}$ Gregory thought of himself as living in the period that began with Pentecost, the apostolic age. He is not saying therefore that the full revelation of the Spirit's deity came after the New Testament Scriptures were completed, but that the Spirit's deity was revealed when he came at Pentecost to dwell with the disciples. It was then that the things which the disciples could not bear before the Passion were taught by the Spirit. 'Of these things, one, I take it,' says Gregory, 'was the deity of the Spirit himself.'62

Even before then, during the earthly ministry of the Son, the deity of the Spirit was 'suggested' or 'secretly shown'. ${ }^{63}$ Within the larger movement of the whole divine economy, the revelation of Father, Son, and Spirit, there is within the scope of the life, death and resurrection of Christ a gradual revelation of the Spirit to the disciples 'according to

${ }^{59}$ For this interpretation of Gregory, cf. G.W. Lampe, God as Spirit (Oxford: Clarendon, 1977) 217.

${ }^{60}$ Orat. 31:26, PG XXXVI, 161C.

${ }^{61}$ Orat. 41:11, PG XXXVI, 444B.

62 Orat. 31:27, PG XXXVI, 164C.

${ }^{63}$ Orat. 31:26, PG XXXVI, 161C: ine\&elk€. 
their capacity to receive him, at the beginning of the gospel, after the Passion, after the ascension'.64 Gregory regards the Paraclete sayings in John as part of the covert or secret showing of the Spirit during the earthly life of Christ. Jesus says that he will ask the Father 'to send' the Paraclete (John 14:16) 'so that he [Jesus] might not seem to be a rival God'.65 But he says the Paraclete 'shall come' to emphasize the Paraclete's own authority as being himself God.

Gregory's doctrine of progressive revelation makes it clear that in his view, the Trinity is revealed in the divine economy. The doctrine of the Trinity (and, within that, the deity of the Spirit) is not based simply on isolated texts, but upon the whole scope of Scripture.66 The acts of God in the divine economy provide the total context within which the texts must be interpreted. These are the $\pi \rho \alpha \gamma \mu \alpha \tau \alpha$, the divine realities or facts, to which the $\delta \nu 6 \mu a \tau a$, the words and names, refer, and the meaning of the $\delta \nu 6 \mu a \tau a$ must be understood with reference to the $\pi \rho \alpha \gamma \mu a \tau \alpha$.

Within the whole scope of the divine economy, it is Pentecost which particularly reveals the distinctiveness and deity of the Holy Spirit. In the Pentecost oration of the previous year, Gregory had spoken of this at more length, interpreting the Johannine Paraclete sayings in the context of the event of Pentecost to which he took them to refer.

For it was fitting that as the Son had lived with us in bodily form, so the Spirit too should appear in bodily form; and that after Christ had returned to his own place, he should have come down to us, 'coming' because he is the Lord, 'sent' because he is not a rival God.... And therefore he came after Christ that a Paraclete should not be lacking to us; but 'another' Paraclete that you might acknowledge his co-equality. For this word 'another' marks an alter ego, a name of equal lordship, not of inequality. For 'another' is not said, I know, of different kinds, but of things consubstantial. ${ }^{67}$

Here Gregory exegetes the Johannine 'another Paraclete' with reference to the Spirit's descent at Pentecost. It is axiomatic for him that the descent of the Spirit at Pentecost as recounted in

\footnotetext{
64 Ibid., 164A.

65 Ibid.

${ }^{66}$ This concept of the okotós of Scripture is Athanasian. Cf. T.F. Torrance, op. cit., 454ff.

67Orat. 41:11-12, PG XXXVI, 444C-445A. Cf. John 16:7; 14:26; 14:15.
} 
Acts 2 is an historical event. Therefore the name (ovvoua) 'another Paraclete' must be understood with reference to this divine deed or fact $(\pi \rho a \gamma \mu \alpha)$. First, the event makes clear the distinction of the Spirit, because it is not the risen Christ in his Resurrection body who comes upon them. The things of the body of Christ are ended; or rather, what belongs to his bodily presence. ${ }^{68}$ Now the things of the Spirit begin and the Spirit comes no longer just in energy or activity upon us, but

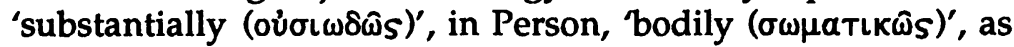
Gregory puts it. ${ }^{69}$ Hence he is said in John to be 'another' Paraclete distinct from the Son. Secondly, the event of Pentecost makes clear the Spirit's deity. For he comes

in the form of tongues because of his close relation to the Word. And they were of fire, perhaps because of his purifying power, or else because of his substance (olviav), for our God is a consuming fire.

The event of Pentecost reveals the deity of the Spirit, his consubstantiality with Father and Son as God. Hence he is said in John to be 'another Paraclete,' since the word 'another' marks not only one who is distinct, but also one who is co-equal.

For this word 'another' marks an alter ego, a name of equal lordship, not of inequality. For 'another' is said, I know, not of different kinds, but of things consubstantial. ${ }^{71}$

The revelation of both the distinctiveness and the coequal deity of the Spirit as consubstantial with Father and Son, one God, is given not in words only, nor in deeds only, but in word and deed given indivisibly. The words or names (ovоната) are interpreted in the light of the deeds or facts ( and with that, of the deity of the Spirit, is inseparably bound up with the divine revelation in the economy, that is, with the historicity of the Biblical account.

The Pentecost oration thus elaborates with reference to Pentecost and the Spirit the general point made in the Fifth Theological Oration, that the deity of the Spirit is an

\footnotetext{
${ }^{68}$ Orat. 41:5, PG XXXVI, 436C.

${ }^{69}$ Orat. 41:11, PG XXXVI, 444C.

70 Orat. 41:12, PG XXXVI, 445A.

${ }^{71}$ Cf. supra, n. 67.
} 
implication of the revelation of the Triune God in the divine economy. Gregory concludes this section on progressive revelation in the Fifth Theological Oration with the reflection already noted that the Spirit who gives us new birth, who deifies us by baptism and so admits us to the new creation, must be worshipped with the Father and the Son, 'distinctively Three, but one Godhead, undivided in honour and glory and substance and kingdom'.

\section{Scriptural Testimonies}

Gregory now approaches the climax and conclusion of his argument. All this, he says,

is what may be said by one who admits the silence of Scripture (To dypaфov). But now the swarm of testimonies shall burst upon you from which the deity of the Holy Spirit shall be shown to all who are not excessively stupid, or else altogether enemies to the Spirit, to be most clearly recognized in Scripture. ${ }^{72}$

In other words, up to this point Gregory has shown that even if the deity of the Spirit were not stated in Scripture it would be implied by the events to which Scripture bears witness. But now, having shown that the whole scope of the divine economy implies and requires the deity of the Spirit, he is going to show that the deity of the Spirit is clearly entered in writing, clearly scriptural. The scriptural proof is that the acts and attributes and titles of God are explicitly attributed to the Spirit. Gregory asks:

What great things are there in the idea of God which are not in his power? What titles which belong to God are not applied to him....?

He answers his own question with a concatenation of almost fifty biblical references. ${ }^{74}$ The scriptural names given include

${ }^{72}$ Orat. 31:29, PG XXXVI, 465AB.

73 Ibid.

74 Luke 1:35; Matt. 1:20; John 1.32, 33; Matt.4:1; Luke 4:1,14; Matt. 12:28, Acts 1:8,9; I. Cor. 2:11,16; Rom. 8:9; II Cor. 3:17; Rom. 8:15; John 14:17; 15:26; 16:13; Isa. 11:2; Ps. 143:10, Ps. 51:10,12; Rom. 15:26; I. Cor. 12:11; Phil. 2:11; II Cor. 13:14; Matt. 12:31; Luke 11:20 (Matt. 12:28); Acts 2:3 (Heb. 12:29); John 3:5; Rom. 8:11; I Cor. 2:10; John 14:26; John 3:8; I John 2:27; John 16:13; Ps. 143:10; Acts 13:2,2; Acts 20:23; Isa. 63:10; Acts 5:9; I Cor. 2:10 ; John 6:63; Rom. 8:10; I 
from Paul 'the Spirit of God' and 'the Spirit of the Lord' who is himself the Lord; from the Johannine discourses 'the Spirit of truth'; and from Isaiah 11:2 'the Spirit of wisdom, of understanding, of counsel, of might, of knowledge, of godliness, of the fear of God'. Among the attributes of God attributed to the Spirit are omnipresence and omnipotence (these from Wisdom), inherent holiness ('sanctifying, not sanctified') and omniscience. The Spirit shares all the divine functions: he 'does all that God does'. ${ }^{75} \mathrm{He}$ is 'the Creator-Spirit who by baptism and resurrection creates anew'.$^{76}$ Blasphemy against him alone cannot be forgiven. Judgment comes upon Ananias and Sapphira who lie to him. Does all this not proclaim, Gregory asks, that the Spirit is God?

Now really, you must be extraordinarily dull and far from the Spirit if you have any doubt about this and need someone to teach you. ${ }^{77}$

Just as to say 'twice five' or 'twice seven' or 'a rational and mortal animal' is to imply 'ten', 'fourteen' and 'man', so in explicitly attributing the titles and acts of God to the Spirit, the Scriptures clearly imply that the Spirit is God. Here it is plainly evident that for Gregory the revelation of the Spirit's deity is not post-scriptural. Gregory does not think in terms of an era or stage of revelation which begins with the completion of the New Testament books or the death of the apostles. For him the present age, the one in which he lives, begins with Pentecost, and is the age when the Spirit is more perfectly revealed. In proclaiming the deity of the Spirit, he does not see himself proclaiming a revelation which is a stage beyond that given to the apostles. In saying explicitly, 'the Spirit is God', he is simply stating what the apostolic Scriptures clearly imply. The present age in which he is living and in which the Spirit is personally present and revealing himself to be God began at Pentecost with the apostles who were to pen the apostolic Scriptures of the New Testament.

Cor. 12:11; Eph. 4:11; Acts 2:3; John 14:16; Matt. 12:31,32; Acts 5:3,4. Also Wisdom 1:7 and Wisdom 7:22-27.

75 Orat. 31:29, PG XXXVI, 168A.

76 Ibid., 165C.

77Orat. 31:30, PG XXXVI, $168 \mathrm{C}$. 
Gregory stands out among the Cappadocian Fathers as the one most ready to declare the deity of the Spirit. Unlike the brothers, Basil and Gregory of Nyssa, and indeed unlike the Council of Constantinople which met the year after his Five Theological Orations and approved the creed we now call the Nicene Creed (and which Gregory left in disgust after being briefly its president), Gregory was prepared to say openly and explicitly that the Holy Spirit is God. That confidence seems to have arisen at least in part from Gregory's belief that the deity of the Spirit was the clear teaching of Holy Scripture. 